\title{
Reviews of Sustainable Rural Development in the Scope of Building New Rural Areas in Vietnam
}

\author{
Nguyen Thi Thu ThuY \\ Szent István University Kaposvár Campus, H-7400 Kaposvár, Guba Sándor utca 40
}

\section{ABSTRACT}

In Vietnam, rural area is a region for living and working of a rural resident community, including mainly farmers. It is a region of agricultural production (by the general meaning). Besides, there are manufacturing activities and service, but priority is given to agriculture and rural community. Meanwhile, the rural density is lower than urban density. Vietnam introduced its development programme "Building new rural areas", which program aims at finding a concept of sustainable development in rural areas in order to emerge the role of sustainable development toward the National direction for local strategies and to ensure sustainable rural development. This paper is a work at the scope of reviews and literature available worldwide in development policies and programmes on sustainable rural development. It compares the dimensions of these policies and programmes on the basis of definitions, methodology and practical framework applied in order to identify a promotion for building new rural areas in disciplines, and especially supply a background for data analyses of the Vietnamese case in the National Target Programme "Building new rural areas during the period 2011-2015".

Keywords: sustainable rural development, sustainability, new rural areas, Vietnam, commune, rural development program, rural development policy

\section{INTRODUCTION}

Rural areas have been in focus of various local, national and international level policies, and most of it explains the relevance of them with its role in food supply, the high proportion of population living there and - in relation with many consequences - the poverty of rural people (Anriquez \& Stamoulis, 2007). The International Fund for Agricultural Development estimated already in 2001 that among the poorest 1.2 billion people in the world, surviving with less than a dollar per day, three out of four lived in rural areas. They constitute the poorest fifth of world population and do not earn enough to cover their food needs. In comparison, In 2018, four out of five people below the international poverty line lived in rural areas globally according to Worldbank (2020). The fight against poverty and for the rise of rural areas is supported by worldwide programmes, however different regional level strategies and programmes call various approaches.

The EU's Rural Development policy supports rural areas to meet the wide range of economic, environmental and social challenges. It's target fields comprise the 
competitiveness of agriculture, the sustainable management of natural resources, and climate action, and a balanced territorial development of rural economies and communities, the creation and maintenance of employment. Rural areas account for $90 \%$ of the territory of the 27 Member States and more than $56 \%$ of the EU's population. As early as in 2008, European Communities stated that agriculture and rural development is central to national and international development agendas due to its contribution to poverty reduction (European Communities, 2008).

In Vietnam, building new rural areas or rural transformation or rural development process is in the centre of the developing country's strategy. Because "There is a firm aspiration that by 2035 , Vietnam will be a modern and industrialized nation moving toward becoming a prosperous, creative, equitable, and democratic society" (World Bank, 2016, p. 17). The Vietnamese state was consistent and determined with its policy orientation to develop the economy in parallel with improving social life and protecting the environment.

\section{LITERATURE REVIEW ON RURAL DEVELOPMENT CONCEPTIONS}

\section{Sectoral approach based rural development}

As rural areas are in large areas, they are affected by natural conditions at diversified levels. To resolve the multi-faceted problems of the rural population in a holistic manner is not possible (Schmidt-Kallert, 2005). Sectoral approaches perceive the rural population in a specific role: i.e., the farmers as food producers, so they focus specifically on "layers" of rural population. This is supported by the approach of European Communities to capture the role and position of Agriculture and Rural Development programme in order to improve rural areas in EU countries. It underlies that rural development lays in a multi-sector concept, including agriculture, rural infrastructures, rural water and forestry (European Communities, 2008).

Specifically, on the farmers' level, the Farming systems research approach (Tanic \& Dixon, 2002) defines the rural development process as a process which encompasses the whole aspects of society, economy, environment, and political position of rural areas and it puts the farmers at the central issue of the solutions.

\section{Participation-based approaches}

Participatory and Negotiated Territorial Development (PNTD) approach proposed the question whether top-down or bottom-up concepts are successful. According to the past 30 years of experiences in technical assistance projects they identified mainly top down, supply-driven approaches. Interventions were defined by sectoral issues (agriculture, natural resource planning and management, soil, and water conservation, etc.). It was found that these interventionas failed adaption to local context as addressed only partially the constraints and potentials of the territories they dealt with $(F A O, 2005)$.

Contrary, collective action theories concentrate also endogenously provided development factors, which can be interpretetd as participation-based, locally induced 
development approaches. These researches' findings may contribute to the main questions to identify endogenous development factors for a small community in the Red River delta in Vietnam.

According to Vanni (2014) the importance of Collective Action theory was supported by the fact that in the last few decades an increasing number of literature on collective action and natural resources has emerged. They extensively discussed the conceptualization of collective action and the analytical framework necessary to study it.

From the point of view of methodology to study collective actions, the most important finding is that among factors that affect emergence, as well as performance of agriculture, natural resource management and rural development programs in developing countries "Cooperation has always been fundamental for human society and played a particularly prominent role in rural development programs" (Meinzen-Dick et al., 2004, p. 1) The evidence for collective actions cover include collective decision-making, setting rules of conduct of a group and designing management rules, implementing decisions, and monitoring adherence to rules.

The collective actions was defined by Meinzen-Dick et al. (2004) as it "requires the involvement of a group of people, ... a shared interest within the group and it involves some kind of common action which works in pursuit of that shared interest. ... This action should be voluntary, to distinguish collective action from hired or "corvee" labor...". (Meinzen-Dick et al., 2004, p. 4)

\section{Definitions of rural areas}

Looking back at some main approaches to study "rural development" in a theoretical scope, this paper would research the real challenges and achievements of rural development programmes to overcome the difficulties of transformation of living conditions in order to make rural areas attractive and viable places, thus stopping migration of farmers to cities.

\section{Theoretical framework of rural development and sustainable rural studies}

In general, to draw attention to rural areas is not easy by a unique conception in rural studies. This paper discusses here different rural development conceptions.

\section{Vietnam}

In Vietnam, rural areas are the settlement for living and working of communities with mainly activities of agricultural production. Rural areas locate in large areas where nature - society - economics differ significantly. Meanwhile, rural areas are the places to supply foodstuff for living, to supply raw material, goods for industry and export, labor for industry and urban areas. It is also the large market for consumption of industrial goods and services. However, the difference between rural and urban areas in Vietnam is not only the type of job of rural residents but also the difference of natural and socio-economic aspects. So, a conception of rural areas was formulated like this: "it is a large area with a community of residents in which they work for agriculture (agriculture, forest, and fishery), it has a low population density, behind 
legging infrastructure, low educational, technological and scientific qualification, and the living standard of rural residents is lower than urban citizens" (Thang \& Dinh, 2002, p. 10).

\section{European Union}

Rural areas are defined as "those parts of the space economy which are least affected by the process of urbanization and are therefore more associated with a much more dispersed pattern of population distribution and economic activity." Therefore, " $[t]$ hey are also affected by varying levels of peripherality, depending on their distance from markets and their access to service." (Grimes, 2000, p. 13).

\section{Food and Agriculture Organisation}

According to the ESA Working Paper No. 07-02 of FAO, two main methodologies are used to define the 'rural'. "The first methodology is to use a geopolitical definition. Because urban is defined by law as all the state, region, and district capitals (centers), and by exclusion all the rest is defined as rural. The other popular methodology is to use observed population agglomeration to define urban. Therefore, in this case populations that live within an area where contiguous households form populations larger than, say 2,000 inhabitants are considered urban, while by exclusion the rest is defined as rural." (Anriquez \& Stamoulis, 2007, p. 4).

\section{Organisation for Economic Co-operation and Development}

Nowadays, OECD countries operate the common Rural Policy Programme because of the fact that "[t] he success of large numbers of rural regions highlights the potential that can be tapped when rural communities are able to mobilise their place-based assets." (OECD, 2017, p. 2) So, OECD considers the direction of their future work for new diversified rural policy: "[r] ural is not synonymous with agriculture and is not synonymous with economic stagnation" (OECD, 2017, p. 4). Table 1 indicates the different conceptualization of the paradigm shift in rural policy of OECD.

Table 1

\section{Pesaran CD test for cross-sectional dependence}

\begin{tabular}{|l|l|l|}
\hline \multicolumn{2}{|l|}{$\begin{array}{l}\text { From Paradigm } \\
\text { The } 2005 \text { New Rural Paradigm (NRP) }\end{array}$} & $\begin{array}{l}\text { To Policy: Integrating policy } \\
\text { domains to address well-being } \\
\text { dimensions }\end{array}$ \\
\hline Main tools & Investment & Complementarities with cities \\
\hline Objectives & Competitiveness of rural areas & Low density economics \\
\hline $\begin{array}{l}\text { Key target } \\
\text { sector }\end{array}$ & $\begin{array}{l}\text { Holistic approach to inclu- } \\
\text { de various sectors of rural } \\
\text { economies }\end{array}$ & $\begin{array}{l}\text { Better understanding of the variety } \\
\text { and diversity of rural areas }\end{array}$ \\
\hline Key actors & Multi-level governance & Toolkits/Policy dialogue \\
\hline
\end{tabular}

Source: OECD, 2017, p. 7 
The traditional definition of rural as 'not urban' still lingers in some countries. The OECD regional typology is based on two main territorial levels. Besides this, OECD countries have three types of important distinction for rural regions (Table 2).

Table 2

\section{The OECD regional typology - Three types of rural regions}

\begin{tabular}{|l|l|l|l|}
\hline \multicolumn{2}{|l|}{ The Territorial Level 2 (TL2) } & The Territorial Level 3 (TL3) \\
\hline $\begin{array}{l}\text { - the first level below the national } \\
\text { one } \\
\text { - administrative units in most } \\
\text { countries }\end{array}$ & $\begin{array}{l}\text { - the territorial level above the local level } \\
\text { - administrative units in some countries }\end{array}$ \\
\hline \multicolumn{3}{|l|}{} & \multicolumn{2}{|l|}{$\begin{array}{l}\text { predominantly } \\
\text { urban }\end{array}$} & $\begin{array}{l}\text { intermedi- } \\
\text { ate rural }\end{array}$ & $\begin{array}{l}\text { predominantly } \\
\text { rural }\end{array}$ \\
\hline $\begin{array}{l}\text { Rural inside the functi- } \\
\text { onal urban area (FUA) }\end{array}$ & $\begin{array}{l}\text { Rural outside but in clo- } \\
\text { se proximity to the FUA }\end{array}$ & $\begin{array}{l}\text { Rural is remote from the } \\
\text { FUA }\end{array}$ \\
\hline $\begin{array}{l}\text { These rural areas are part } \\
\text { of the catchment area of } \\
\text { the urban core and their } \\
\text { development is intimately } \\
\text { linked to that of the city. }\end{array}$ & $\begin{array}{l}\text { These rural communities } \\
\text { often enjoy a good in- } \\
\text { dustrial mix, which makes } \\
\text { their local economies } \\
\text { more resilient. }\end{array}$ & $\begin{array}{l}\text { Primary activities play a } \\
\text { relevant role in the regional } \\
\text { economy. }\end{array}$ \\
\hline
\end{tabular}

Source: Based on OECD, 2017

Those disciplines above support significant keys for the process of decision-making about rural development policies and accordingly to the relation with agricultural development policies, especially for the process of building new rural areas in Vietnam.

The following part of the paper discusses rural development and programmes in different practices.

\section{RURAL DEVELOPMENT PROGRAMMES}

\section{World Bank}

As early as the Sector paper of World Bank in 1975 presented the guidance of rural development programme and this knowledge is still an effective basis for developing countries at present, especially for the case in Vietnam. It advises that a national program for rural development includes a variety of activities, targeting to raise agricultural output, create new employment, improve health and education, expand communications and improve housing (World Bank, 1975).

\section{Food and Agriculture Organisation}

Contrary, FAO considers rural development as one with "particular reference to agriculture". It recognizes agriculture as the basis of the livelihood of most rural families, and therefore the basis for the development of rural areas. FAO defines 
rural development as a "process of analysis, problem identification and the proposal of relevant solutions. This process is usually encompassed within a programme or a project which seeks to tackle the problem identified" (Oakley \& Garforth, 1985, p. 29). Although, this approach is criticized by the author: the problems that rural development programmes attempt to solve are diverse, the programmes should not focus only on agriculture but the social or institutional problems in rural areas, too. Therefore, rural development strategies and programmes implement complex projects in a specific rural area. These provide basis for government and non-government efforts, and they include both agricultural and non-agricultural projects. The principles of rural development programmes according to Oakley- Garforth is presented in Table 3.

Table 3

\section{Principles of rural development programmes}

\begin{tabular}{|l|l|}
\hline 1. Access & $\begin{array}{l}\text { Ensure that the programme and its benefits can reach those in } \\
\text { need. }\end{array}$ \\
\hline 2. Independence & Devise a programme which helps and supports the farmers. \\
\hline 3. Sustainability & $\begin{array}{l}\text { Ensure that the programme's plans and solutions are relevant to } \\
\text { the local economic, social and administrative situation. }\end{array}$ \\
\hline 4. Going forward & $\begin{array}{l}\text { Technological aspects should help the farmers to take the next } \\
\text { step in the development. }\end{array}$ \\
\hline 5. Participation & $\begin{array}{l}\text { Try to consult the local people, find out their ideas and involve } \\
\text { them as much as possible in the programme. }\end{array}$ \\
\hline 6. Effectiveness & $\begin{array}{l}\text { A programme should be based on the effective use of local } \\
\text { resources and not necessarily on their most efficient use. }\end{array}$ \\
\hline
\end{tabular}

Source: Oakley \& Garforth, 1985, p. 38

For the case of the National Target Programme Vietnam for building new rural areas during the period 2011-2015, each actor of the RD programme (decision-makers, stakeholders, groups, communities, organizations...) can have different approach for the implementation to reach the different outcomes within the main principles.

\section{International Fund for Agricultural Development}

In the IFAD Report 2016 about rural development, a transition of rural areas toward an inclusive growth was defined: "Inclusive rural transformation is ... a critical component of inclusive growth as a whole, of sustainable development in all its dimensions - social, economic and environmental. It is both a vision and a lens through which to interpret historical processes in rural areas across the world" (IFAD, 2016, p. 263). This process defined a preservation of the rural heritages but also a promotion of all-inclusive growth to create a sustainable development for rural areas and it supports important lessons for the case of Vietnam for building new rural areas during the period 2011-2015. 


\section{Vietnam}

The point of view on rural economic development is in the process of industrialization and modernization by four major dimensions. First, an effective rural economic development must contain three pillars: society, economics and environment. Second, the rural development must have a multidimensional rural economy under the market mechanism and the management of the state. Third, the development of rural areas should be done comprehensively regarding to the comparative advantages of different regions. Rural development is not only economic development but also a development of society and security, and environmental protection. Rural development is not only a development in the agricultural sector but also in industry and service. Fourth, rural development has goals in industrialization and modernization by eradicating lagging behind of rural areas, building rich and civilized rural areas to tackle rural areas toward industrialization and modernization (Thang \& Dinh, 2002).

Generally, to find a concept of sustainable development in rural areas to emerge the important role of sustainable development toward the National direction for local strategies and to deal with sustainable rural development in Vietnam is the aim in this section.

\section{SUSTAINABLE DEVELOPMENT OF RURAL AREAS}

The multi-faceted goals of rural development including maintenance and improvement of natural resources and economic growth calls the definition of sustainable rural development.

\section{Sustainable development in OECD countries}

According to OECD, sustainable development means integrating the economic, social and environmental objectives of society It targets to maximise human well-being in the present without compromising the ability of future generations to meet their needs. The task is to improve the coherence and complementarity of policies across a wide range of sectors, in order to respond to the complex development challenges (OECD, 2001).

\section{Vietnam}

In Vietnam, it was realized that: "sustainability is a method of reasonable development". Economic globalization has a wide effect on economic development, but it has to meet the goals of economic-social-environmental effects and sustainability harmoniously and comprehensively (Dung et al., 2010).

\section{Rural development policy reforms in the European Union (EU)}

In the European Union, rural development policy promoting sustainable economic, social, and environmental development is integrated as a component of the common agricultural policy (CAP) (European Commission, 2006).

Decoupling of price support, area payment and aids for diversification of rural economy has been taken place through consecutive reforms of CAP (in 1960, 1992, 
$1995,2003)$, while more emphasis has been put on animal welfare and nature conservation actions, in further modifications of the programme $(2005,2007)$ that brought EU Rural Development Regulation (RDR) into effect (Borec - Turk, 2009).

Furthermore, historical evolution of rural development policy in the EU is also integrated with the Cork Declarations (1996, 2016), and Leader initiative. First, the Cork declaration (1996) aimed at improving Living countryside through ten points (European Commission, 1997); later, the Cork 2.0 Declaration defines ten policy orientations with the aim of providing Better life in rural areas in an innovative, integrated and inclusive rural and agricultural policy with special regards to Promoting Rural Prosperity, Strengthening Rural Value Chains, Investing in Rural Viability and Vitality, Preserving the Rural Environment, Managing Natural Resources, and Encouraging Climate Action (European Union, 2016). There is an inheritability conjunction from Declaration in 1996 to version in 2016. This is a coherent, integrated implementation of rural development policy to get well-being and wealth for rural resident and get attention for the effective green growth for rural areas of EU countries.

\section{LEADER approach}

LEADER Community Initiative has enabled new paths to be taken in rural development for the task of revitalising rural areas in the EU countries. Leader stands for 'Links between actions of rural development'. Leader approach is a tool that works well, in quite different situations and types of areas, thus adapting rural policymaking to the extreme diversity of rural areas' needs. For these reasons, it has now become an integral part of rural development policy. It is an area-based and bottom-up approach, involving local communities and adding value to local resources, gradually came to be seen as a new way of creating jobs and businesses in rural areas. Leader began in an experimental way bringing together, at local level, various projects and ideas, stakeholders and resources. It proved to be an ideal instrument for testing how to expand opportunities for rural areas (European Commission, 2006)

In the rural development context, LEADER is implemented under the national and regional Rural Development Programmes (European Communities, 2014) (RDPs) of each EU Member State, co-financed from the European Agricultural Fund for Rural Development (EAFRD) (European Union, 2017). It aims at forming multi-stakeholder networks for rural development and strategies on the mutual partaking in development programmes.

So, the overall circumstance of rural development policy and/or programme in the EU is lessons to learn for rural development policy and programme in Vietnam. Finding impacts of sustainable rural development in the EU can be seen as a target learning in building new rural areas in Vietnam at present.

The notions of the three pillars of economic, social and environmental aspects are correlative with the concepts of rural areas, rural development and sustainable development. It is clear that the basic and specific disciplines in rural studies and the studying of rural development are the key notes for data analysis of the $\mathrm{RD}$ programmes 


\section{MATERIALS AND METHODS}

Deriving from the judgment of the relation between theory and practice in studying rural development, I had carried out a preliminary research through various approaches.

In this paper I discuss criticism about sectoral approaches of rural development and highlight the importance of and compare participation-based approaches through international practices. The selection of publications and materials used as secondary sources for this analysis was based on that they cover the general concept of approaches to rural development programmes and policies.

In further part of this paper the conceptions of rurality are discussed on the basis of articles and policies. The review covers the definitions of rural areas, rural development (and programmes) and sustainable development of rural areas - comparing the European practice and Vietnamese evidences.

The other half of the paper introduces the so called practical framework for rural development from the context of rural characteristics of Vietnam. The source of secondary data shown here is the national statistical office; and Vietnam's development programme was used as secondary information source. The Results and discussion part also covers lessons to learn from EU and international practice.

\section{RESULTS AND DISCUSSIONS}

In this section, I present a practical framework about rural development to have a real comparison of rural development policy and programme in the EU and in Vietnam.

\section{Characteristics of rural areas in Vietnam}

Rural areas have a vital role and position in the development of the country. Rural areas is a region where foodstuff for basic needs and supply cereals, raw materials for industry and export are produced. For several years, the agricultural sector has produced $40 \%$ of national income and $40 \%$ of export value to create a cumulative source for industrialization and modernization for the country. It supplies profuse human resources for society derive from, it gives $67.95 \%$ of the labor force. However, in industrialization and modernization, there is transfer of rural labor. They have moved to work for industry and service in urban areas and industrial zones. Rural areas accounted $67 \%$ in 2013 and reduced to $65 \%$ in 2016 regarding the whole population of the country. So, rural areas in Vietnam are still a large market of domestic consumption of industrial and service products (Figure 1).

Rural areas has over 50 ethnic groups living together, including many different members, classes, beliefs, and religions and this is a basis to guarantee a stable socioeconomic condition of the country and to strengthen the unity of ethnic communities.

Rural areas are placed in the large areas where there are different natural, economic and social conditions. That is a huge potential of land, minerals, fishery for sustainable development. (Thang \& Dinh, 2002). 


\section{Figure 1}

\section{Population in Vietnam by gender, urban - rural areas and labor force period 2010-2016}

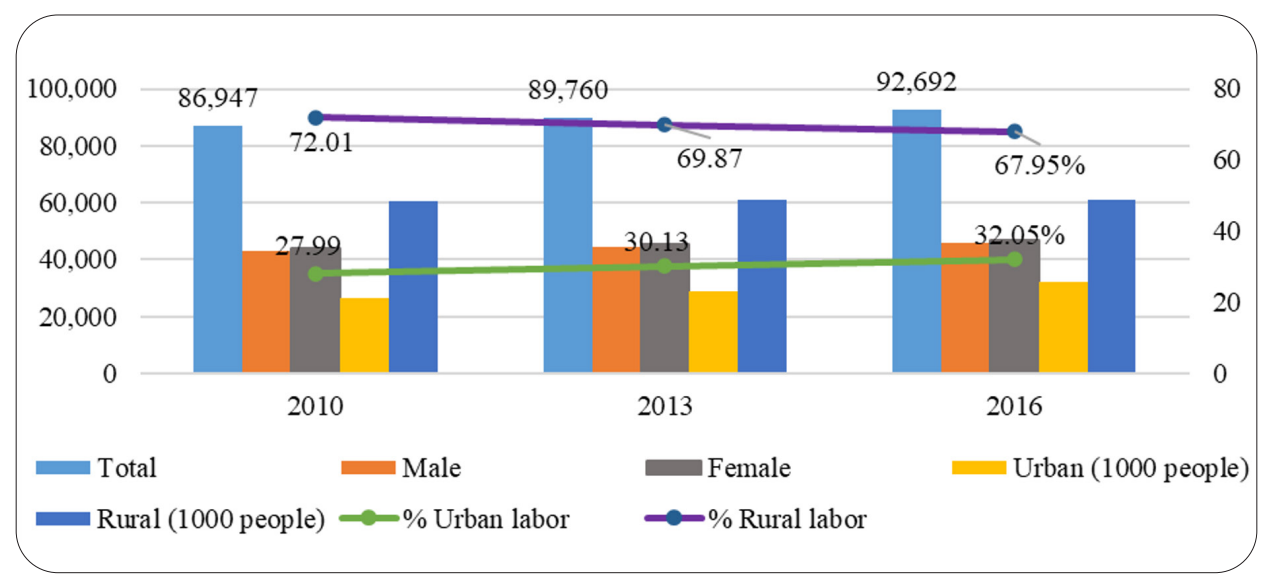

Source: GSO, 2018a; GSO, 2018b

Therefore, the agricultural and rural development policies in Vietnam are always based on those special characteristics which decide all orientations of the Government and the State in this section.

\section{Rural development policy at present in Vietnam}

Rural, agricultural policy is the overall economic and other methods of the State (from central to local) affecting agriculture, rural areas and all fields, sectors in rural areas and agriculture (Khoi, 2007). The rural policy targets not only the economic activities but also particular social activities. As job, poverty, population, rural custom, rural traditional living issues may differ from urban areas, an intervention into economic activities and the influence on social activities are very important directions of rural development policies (OECD, 2015).

Vietnam Sustainable Development Strategy 2011-2020 is a point of view of state management about sustainable development on a macroeconomic level in Vietnam. It considers human beings as the center of sustainable development. Creation of favorable conditions is important for individuals and community in order to have equal opportunity to develop talents; access to joint resources; and participate in building of, contribute to and benefit from knowledge, material and cultural backgrounds for the next generations.

Vietnam SD Strategy 2011-2020 approved the general objectives as the aims to achieve sustainable rural development from three aspects. The economic aspect aims at the process of urbanization and modernization of rural areas which needs to comply with the norms of building new rural areas, decrease the development gap between urban and rural areas. Figure 2 illustrates the regional and quintile incomes in Vietnam. 
Figure 2

Monthly income and Income quintile in Vietnam by VHLSS 2016

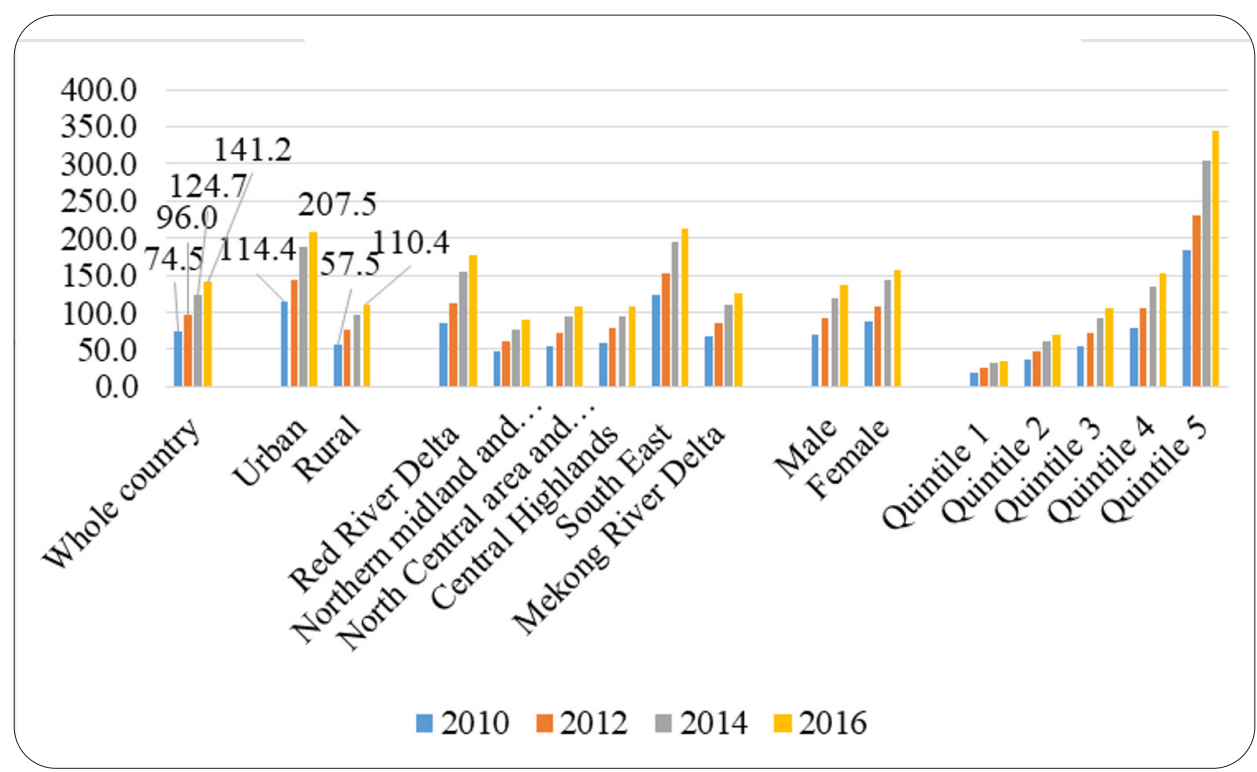

Source: GSO, 2018a; GSO, 2018b

Figure 2 indicated challenges of the income gap between rural and urban areas which occurred among regions in Vietnam and reflected upon the reality of wealth by income generation and affected consumption expenditure.

The third, social aspect is developing urban areas, building new rural areas and allocating population and labor in each region properly and sustainably. Figure 3 illustrates the income inbalances in Vietnam.

Imbalances of incomes increased according to above statistics, although in urban regions, variation of GINI is more moderate and these regions seem less vulnerable than rural areas.

The aspect of maintaining resources and environment includes degradation prevention, effective and sustainable use of land resources; protection of water environment and sustainable use of water resources; protection of marine, coastal, island environment; forest protection and development; reduction of impacts, climate change adaptation, prevention of natural disasters (Dung, 2012).

\section{The National Target Programme for building new rural areas in Vietnam}

The reality of practical framework of rural development policies are not comprehensive for performance in rural areas in Vietnam at present. They should be put in and operated by National Target Programmes and National Development Strategies under the conduct of the Government. 
Figure 3

\section{GINI coefficient in Vietnam by VHLSS 2016}

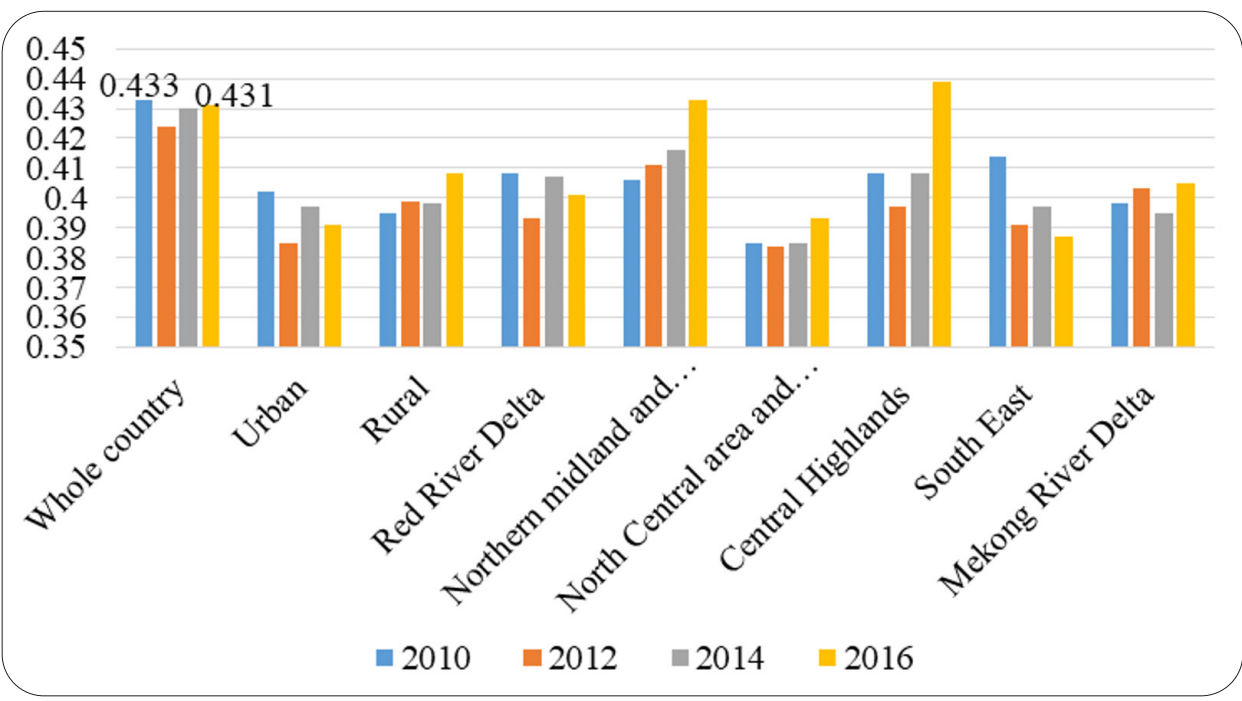

Source: GSO, 2018a; GSO, 2018b

The National Target Programme for building new rural areas in the 2010-2020 period and vision into 2030 was worked out by the government to build new rural areas in Vietnam. It will produce socio-economic infrastructure, economic structure and organization production models reasonably that combine agriculture with developed industry and service; combine rural development and urban development programs. According to this programme, rural society must be democratic, sustainable, rich of ethnic culture; its ecosystem is prevented; its entertainment and spirit of life is improved.

\section{CONCLUSIONS}

This paper's literature review chapter aims at the synthesis of conceptions, definitions, and approaches in rural studies in general and in rural development studies to describe an overarching understanding about rural areas and sustainable rural development. Every piece of literature in this chapter explained the essence of progress of socio-economic growth and development in rural areas, but this progress should depend on the characteristics of each economic model all over the world.

To sum up we can say that this paper contains analyses of theoretical and practical framework in rural development studies to conceive the significant lessons and important keys for decision making, for effective institutions of rural development policy and rural development programmes. Especially, this research work can recognize the target lessons by analyses of all literature as the goals to support the implementation of the National Target Programme building new rural areas in Vietnam in the first stage during the years $2011-2015$. 


\section{REFERENCES}

Anriquez, G., Stamoulis K. (2007). Rural Development and Poverty Reduction; Is Agriculture Still the Key? electronic Journal of Agricultural and Development Economics 4(1), 5-46.

Borec, A.; Turk, J. (2009). Sustainable rural development - EU Agricultural perspective. Journal for Geography, 4(1), 37-52.

Dung, N. M., Thuy, V. T. P., Song, N. V. (2010). Textbook of Environmental economics, Textbook, Chapter 2. Giáo trình Kinh té Môi trúóng, 27. p. Hanoi University of Agriculture, Hanoi, Vietnam

Dung N. T. (2012). Decision of the Prime Minister on April 12, 2012 signed Decision No. 432/QD-TTg on approving the Viet Nam Sustainable Development Strategy for the 2011-2020. http://www.chinhphu.vn/portal/page/portal/English/strategies/strategiesdetails?categoryId $=30$ \&articleId $=10050825$

European Commission (1997). The LEADER approach. http://enrd.ec.europa.eu/ enrd-static/leader/leader/leader-tool-kit/the-leader-approach/en/the-leader-approach_en.html

European Commission (2006). The Leader approach: A basic guide. https://enrd. ec.europa.eu/sites/default/files/2B953E0A-9045-2198-8B09-ED2F3D2CCED3.pdf

European Communities (2008). Sector Approaches in Agriculture and Rural Development. Reference Document No.5, https://doi.org/10.2783/34441

European Union (2016). Cork 2.0 Declaration "A Better Life in Rural Areas". https://enrd.ec.europa.eu/sites/enrd/files/cork-declaration_en.pdf

European Union (2017). EU Rural Review 23 ,Green Economy - Opportunities for Rural Europe online. https:/enrd.ec.europa.eu/sites/enrd/files/publi-enrd-rr23-2017-en.pdf

European Communities, (2014). EU Rural Development Policy 2007-2013. https:// doi.org/10.2762/41007

FAO (2005). An approach to rural development: Participatory and Negotiated territorial development (PNTD). http://www.fao.org/3/ak228e/ak228e.pdf

Grimes, S. (2000). Rural areas in the information society diminishing distance or increasing learning capacity? Journal of Rural Studies 16(1), 13-21. https://doi. org/10.1016/S0743-0167(99)00027-3

GSO (2018)a: Result of the Vietnam Household Living Standards Survey 2016 (VHLSS 2016) General Statistics Office, Hanoi, Vietnam

GSO (2018)b: Statistical Yearbook of Viet Nam 2017. General Statistics Office. Hanoi, Vietnam

IFAD (2016). Rural Development Report 2016: Fostering inclusive rural transformation. 378. p. https://www.ifad.org/documents/38714170/39155702/Rural+development+report+2016.pdf/347402dd-a37f-41b7-9990-aa745dc113b9 
Khoi, P. V. (2007). Analysis for Agricultural, Rural Policy. Textbook. Giáo trình Phân tích chính sách nông nghiép, nông thôn, 207 p. National Economics University, Hanoi, Vietnam

Meinzen-Dick, R., Di Gregorio, M., McCarthy, N. (2004). Methods for studying collective action in rural development. CAPRi Working Paper No. 33., 37. p. International Food Policy Research Institute. Washington. USA

OECD (2001). Sustainable development strategies. What are they and how can development co-operation agencies support them? https://www.oecd.org/dac/environment-development/1899857.pdf

OECD (2015). Agricultural policies in Vietnam 2015. OECD Food and Agricultural Reviews, https://doi.org/10.1787/24114278

OECD (2017). New Rural Policy: Linking Up for Growth. Background Document - National Prosperity Through Modern Rural Policy Conference. 36. p. URL: https://www.oecd.org/rural/rural-development-conference/documents/ New-Rural-Policy.pdf

Oakley, P., Garforth C. (1985). Guide to Extension Training. 53. p. Food and Agriculture Organization of the United Nations, Rome, Italy, https://pdf4pro.com/ $\mathrm{cdn}$ /guide-to-extension-training-food-and-agriculture-4ce6a.pdf

Schmidt-Kallert, E. (2005). A short introduction to micro-regional planning. 42. p. Sub-regional Office for Central and Eastern Europe Budapest, http://www.ips. raumplanung.tu-dortmund.de/cms/Medienpool/Publikationen-Schmidt-Kallert/MicroRegionalPlanning_FAO_en_2005.pdf

Tanic, S., Dixon, J (2002). Farming Systems Based Strategies for Improved Rural Livelihoods in Eastern Europe and Central Asia. Program and abstract book: Conference $17^{\text {th }}$ Symposium of the International Farming Systems Association, University of Florida. November 17-20, 2002 Lake Buena Vista, Florida USA http://www1.montpellier.inra.fr/petitesfermes/docs/Ordi-1015.pdf

Thang, V. D., Dinh H. V. (2002). Rural development economics. Textbook, Chapter 1, Chapter 2, Giáo trình Kinh té phát trién nông thôn. National Economics University, Hanoi, Vietnam

Vanni F. (2014) The Role of Collective Action. Agriculture and Public Goods, 21-37. https://doi.org/10.1007/978-94-007-7457-5_2

World Bank (1975). Rural development: sector policy paper. https://documents.worldbank.org/en/publication/documents-reports/documentdetail/688121468168853933/rural-development-sector-policy-paper

World Bank (2016). Vietnam 2035 Toward Prosperity, Creativity, Equity, and Democracy. https://doi.org/10.1596/978-1-4648-0824-1

World Bank (2020). Poverty. https://www.worldbank.org/en/topic/poverty/overview 
Correspondent author:

\section{Nguyen Thi Thu ThuY}

Szent István University Kaposvár Campus

Doctoral school for Management and Organizational Science

H-7400 Kaposvár, Guba Sándor utca 40.

e-mail: thuyszierwg@gmail.com

(C) Copyright 2020 by the authors.

This is an open access article under the terms and conditions of the

Creative Commons attribution (CC-BY-NC-ND) license 4.0.

$$
\text { (c) }(9)
$$

